\title{
Timothy hays differing in dietary cation-anion difference affect the capability of dairy cows to maintain their calcium homeostasis
}

\author{
V. S. Heron, ${ }^{*}$ G. F. Tremblay, $†$ and M. Oba*1 \\ *Department of Agricultural, Food and Nutritional Science, University of Alberta, Edmonton, AB, Canada, T6G 2P5 \\ †Agriculture and Agri-Food Canada, Soils and Crops Research and Development Centre, Québec, QC, Canada, G1V 2J3
}

\begin{abstract}
Forages low in dietary cation-anion difference (DCAD) can be used to decrease the DCAD in prepartum diet but the extent to which DCAD needs to be reduced is of recent interest. The objective of this study was to evaluate the effectiveness of timothy hays differing in DCAD at maintaining Ca homeostasis. Six nonlactating and nonpregnant multiparous Holstein cows were fed diets containing timothy (Phleum pratense L.) hay with DCAD values of $4.1 \pm 3.6(\mathrm{LOW}), 14.1 \pm 3.0(\mathrm{MED})$, or $25.1 \pm 2.5(\mathrm{HIGH}) \mathrm{mEq}$ per $100 \mathrm{~g}$ of $\mathrm{DM}$ in a duplicated $3 \times 3$ Latin square design with 14-d experimental periods. The LOW and MED hays were produced by fertilizing established timothy fields at a rate of $224 \mathrm{~kg}$ $\mathrm{CaCl}_{2}$ per ha, and HIGH hay was obtained from the same field where LOW hay was produced, but from a section not fertilized with $\mathrm{CaCl}_{2}$. Experimental diets, containing LOW, MED, or HIGH timothy hay at $71 \%$ of dietary DM, had DCAD values of $0.7,7.3$, and 14.4 $\mathrm{mEq}$ per $100 \mathrm{~g}$ of $\mathrm{DM}$, respectively. Animals were fed at $6 \%$ of metabolic body weight, which provided $108 \%$ of their daily energy requirement. For each period, after a $12 \mathrm{~d}$ diet adaptation, cows were subjected to an EDTA challenge (3 cows each on d 13 and 14). Infusion of EDTA solution into the jugular vein decreases the concentration of blood ionized $\mathrm{Ca}$, and the EDTA challenge protocol determined the resistance time and recovery time: the time required for the blood ionized Ca concentration to decrease to $60 \%$, and the time required to recover to $90 \%$ of the prechallenge concentrations, respectively. Urine $\mathrm{pH}$ was lower when cows were fed LOW compared with HIGH diet (6.88 vs. 7.83), but urine $\mathrm{pH}$ when cows were fed MED diet (7.15) did not differ from that when cows received the LOW or HIGH diet. However, immediately before the EDTA challenge, blood $\mathrm{pH}$ was lower when cows were fed LOW or MED compared with HIGH diet (7.44 vs. 7.47). Although the resistance time was not affected by treatments, the
\end{abstract}

Received May 13, 2008.

Accepted August 28, 2008.

${ }^{1}$ Corresponding author: masahito.oba@ualberta.ca recovery time was shorter when cows were fed the LOW compared with MED or HIGH diet (185 vs. 248 and 263 min, respectively). Blood $\mathrm{pH}$ decreased when cows were fed the LOW or MED diet, but the capability to maintain Ca homeostasis was enhanced only when cows received the LOW diet, in which the DCAD value was decreased to $1 \mathrm{mEq}$ per $100 \mathrm{~g}$ of DM.

Key words: EDTA challenge, dietary cation-anion difference, timothy hay, hypocalcemia

\section{INTRODUCTION}

Parturient paresis is a metabolic disorder that negatively affects productivity of lactating dairy cows. This metabolic disorder potentially reduces the productive lifetime of a dairy cow by $3.4 \mathrm{yr}$ and may increase the risk of other metabolic disorders such as mastitis or uterine prolapse after calving (Horst et al., 1997). Supplementation of anionic salts to decrease DCAD was proposed as a management tool to decrease the occurrence and severity of milk fever in dairy cows (Horst et al., 1997). Greater dietary anion intake is expected to decrease blood $\mathrm{pH}$ and increase blood ionized $\mathrm{Ca}$ (iCa) concentration by actions of parathyroid hormone (PTH) and 1,25-dihydroxyvitamin D $\left[\mathbf{1 , 2 5}(\mathbf{O H})_{2} \mathbf{D}\right.$; Goff et al., 1991]. The PTH acts synergistically with $1,25(\mathrm{OH})_{2}$ D to increase osteoclast activity mobilizing bone Ca (Yarrington et al., 1977; Goff et al., 1991; Block, 1994). However, feeding anionic salts or acidifying agents during the dry period often decreases DMI (Charbonneau et al., 2006), increasing the risk of other metabolic disorders.

Feeding low-DCAD forages is another management approach to decrease the severity of hypocalcemia (Charbonneau et al., 2008; Penner et al., 2008). Timothy (Phleum pratense L.) is low in potassium concentration and DCAD value, calculated as $\mathrm{Na}^{+}+\mathrm{K}^{+}-\mathrm{Cl}^{-}-\mathrm{S}^{2-}$ (Ender et al., 1971), compared with other cool-season grasses (Tremblay et al., 2006), and its DCAD can be further decreased with chloride fertilization (Oba et al., 2007; Pelletier et al., 2007, 2008). Penner et al. (2008) fed prepartum dry cows with low- or high-DCAD timothy hay (1.2 vs. $21.6 \mathrm{mEq}$ per $100 \mathrm{~g}$ of $\mathrm{DM})$, and re- 
Table 1. Nutrient composition of the low-, medium-, and high-DCAD timothy hays ( $\mathrm{n}=3$ for each hay)

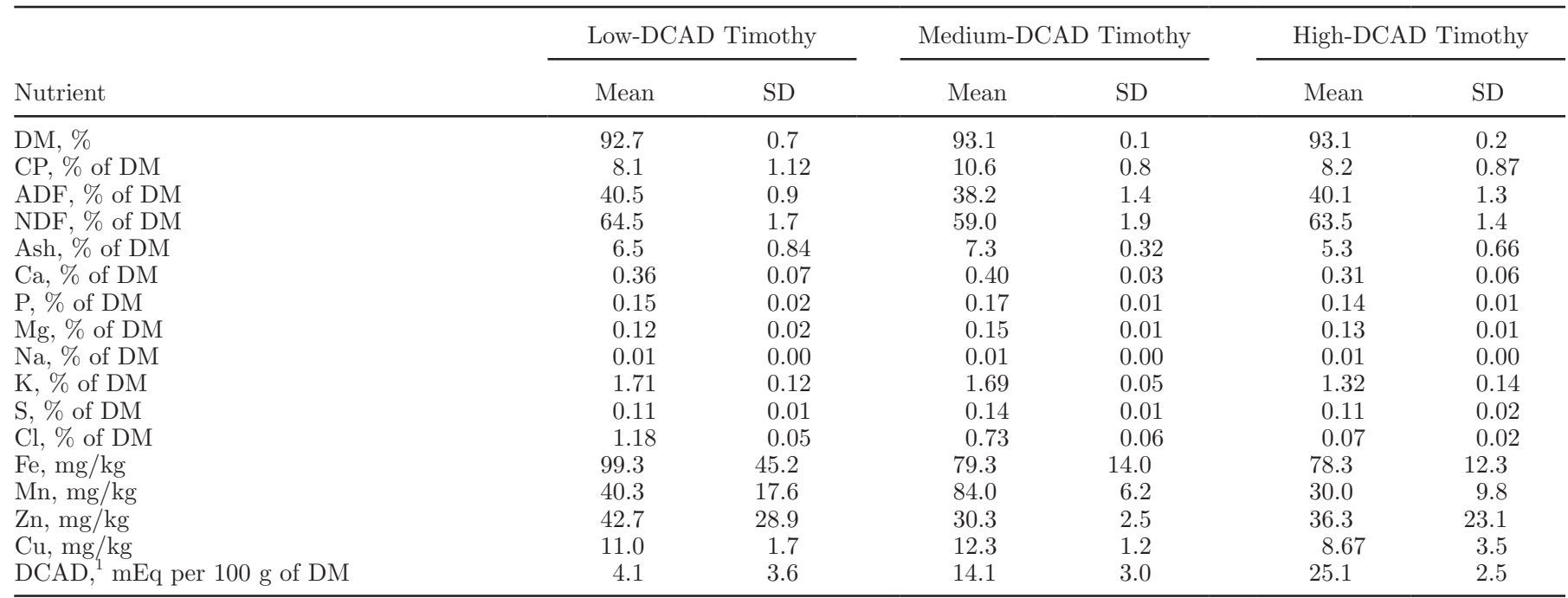

${ }^{1}$ Calculated as $\mathrm{Na}^{+}+\mathrm{K}^{+}-\mathrm{Cl}^{-}-\mathrm{S}^{2-}$ (Ender et al., 1971).

ported that the diet containing low-DCAD timothy hay at $63 \%$ of dietary DM improved Ca homeostasis during the periparturient periods without decreasing DMI.

It was suggested that the DCAD needs to be -5.0 to $-10.0 \mathrm{mEq}$ per $100 \mathrm{~g}$ of DM to prevent hypocalcemia (Horst et al., 1997), but diets with low but positive DCAD also can improve Ca homeostasis around parturition (Kurosaki et al., 2007; Penner et al., 2008). The optimal DCAD that accounts for both reducing the prevalence and severity of hypocalcemia and minimizing depression in DMI has not yet been established. The use of low-DCAD forages in place of anionic salts does not drastically decrease the DCAD in prepartum diets. Thus, it is of interest to determine the extent to which DCAD needs to be reduced to exert physiological responses to prevent hypocalcemia.

The objective of this study was to evaluate the effects of slightly positive DCAD diets containing timothy hays varying in DCAD on the capability to maintain Ca homeostasis in nonpregnant, nonlactating Holstein cows in response to an EDTA infusion challenge.

\section{MATERIALS AND METHODS}

This experiment was conducted from May to July 2007 at the Metabolic Unit of Edmonton Research Station of the University of Alberta (Edmonton, AB, Canada). Experimental procedures were approved by the Faculty Animal Policy and Welfare Committee and conducted according to the guidelines outlined by the Canadian Council of Animal Care (Ottawa, ON, Canada).

\section{Experimental Design and Dietary Treatments}

Three lots of timothy hay varying in DCAD were obtained from established timothy stands near Lethbridge, Alberta, Canada. Low-DCAD (LOW) and high-DCAD (HIGH) timothy were grown on the field under a pivot irrigation system. The soil $\mathrm{K}$ content at this site was $486 \mathrm{~kg} / \mathrm{ha}$, and the field was fertilized with $112 \mathrm{~kg}$ of $\mathrm{N} / \mathrm{ha}$ as urea, and $39 \mathrm{~kg}$ of $\mathrm{P} / \mathrm{ha}$ as monoammonium phosphate on April 15, 2006. In addition, anhydrous calcium chloride $\left(\mathrm{CaCl}_{2}\right)$ was applied using a fertilizer broadcaster to the area between the second and third pivot towers at a rate of $224 \mathrm{~kg} / \mathrm{ha}(143 \mathrm{~kg}$ of Cl/ha) on April 15 to produce the LOW timothy hay. Control timothy hay (HIGH) was grown on the area between the fourth and fifth pivot towers of the same field. The medium-DCAD (MED) timothy was grown on another field with soil $\mathrm{K}$ content of $387 \mathrm{~kg} / \mathrm{ha}$. The field was fertilized with $134 \mathrm{~kg}$ of $\mathrm{N} / \mathrm{ha}$ as urea, and $45 \mathrm{~kg}$ of P/ ha as monoammonium phosphate, and $143 \mathrm{~kg}$ of $\mathrm{Cl} / \mathrm{ha}$ as $\mathrm{CaCl}_{2}$ using a fertilizer broadcaster. All hays were harvested on July 8 as small rectangular bales weighing approximately $27 \mathrm{~kg}$ each, transported to the University of Alberta (Edmonton, AB, Canada), and stored in a covered shelter. Chloride concentration was 0.07 , 0.73 , and $1.18 \% \mathrm{DM}$, and the DCAD, calculated as $\mathrm{Na}^{+}$ $+\mathrm{K}^{+}-\mathrm{Cl}^{-}+\mathrm{S}^{2-}$ (Ender et al., 1971), was 25.1, 14.1, and $4.1 \mathrm{mEq}$ per $100 \mathrm{~g}$ of DM for HIGH, MED, and LOW timothy hay, respectively (Table 1). Although the same protocol was used for $\mathrm{CaCl}_{2}$ fertilization, the $\mathrm{Cl}$ concentration was less than expected for one lot of timothy hay, which was then used as MED timothy hay for the present study. The reasons why the same 
protocol of $\mathrm{CaCl}_{2}$ application resulted in inconsistent $\mathrm{Cl}$ concentrations were not identified for this study.

Six nonlactating and nonpregnant multiparous Holstein cows $(4.1 \pm 0.4$ yr old; $717 \pm 80 \mathrm{~kg} \mathrm{BW})$ with no previous incidence of milk fever were assigned to treatments in a duplicated $3 \times 3$ Latin square design with 14-d periods. Experimental diets contained either the LOW, MED, or HIGH timothy hay at $71 \%$ of dietary DM, and supplemented with a concentrate mix at $29 \%$ of dietary DM. The DCAD values for experimental diets were $0.7,7.3$, and $14.4 \mathrm{mEq}$ per $100 \mathrm{~g}$ of DM, respectively (Table 2). Body weight was recorded on 2 consecutive days immediately before the start of the first period and on the last $2 \mathrm{~d}$ of each period. Then, animals were fed experimental diets at $6 \%$ of metabolic BW (DMI: $8.3 \pm 0.7 \mathrm{~kg} / \mathrm{d}$ throughout the study), which provided 108\% of their energy requirement. Timothy hay and the concentrate mix were fed separately once daily at $0800 \mathrm{~h}$. Animals were housed in individual pens bedded with wood shavings and had free access to water.

\section{Sample Collection}

On d 6 and 12 of each period, $30 \mathrm{~mL}$ of urine was obtained by manually stimulating micturition from each cow at $5 \mathrm{~h}$ after feeding. Urine $\mathrm{pH}$ was determined immediately after collection using a portable $\mathrm{pH}$ meter (model Accument AP61; Fisher Scientific, Pittsburgh, PA). After a 12- or 13-d diet adaptation period, cows were subject to an EDTA challenge (3 cows each on d 13 and 14) according to the procedure described by Wang and Beede (1992) with some modifications described below. A sterile 7\% (wt/vol) EDTA solution adjusted to $\mathrm{pH} 7.4$ was infused via a catheter inserted into the jugular vein at a constant rate of $0.6 \mathrm{~mL}$ per $\mathrm{h}$ per $\mathrm{kg}$ of BW using an electronic infusion pump (Ismatec IPC 4, Glattbrugg, Swtizerland) until the blood iCa concentration decreased to $60 \%$ of the prechallenge values determined immediately before the start of the infusion. Infusion of EDTA solution into the jugular vein decreases the concentration of blood iCa by chelating iCa. The EDTA challenge protocol determined the resistance time, which is the time required for the EDTA challenge to decrease the blood iCa concentration to $60 \%$, and the recovery time, which is the time required for the iCa concentration to recover to $90 \%$ respective to the prechallenge concentrations.

Blood samples were collected from each cow via another catheter inserted into the contralateral jugular vein once before the start of the infusion of the EDTA solution, every 10 min during the infusion, and every

Table 2. Ingredients and nutrient composition of the low-, medium-, and high-DCAD diets

\begin{tabular}{|c|c|c|c|}
\hline Ingredient, $\%$ of $\mathrm{DM}$ & Low-DCAD diet & Medium-DCAD diet & High-DCAD diet \\
\hline Low-DCAD timothy hay & 70.9 & - & - \\
\hline Medium-DCAD timothy hay & - & 71.0 & - \\
\hline High-DCAD timothy hay & - & - & 71.0 \\
\hline Concentrate $\operatorname{mix}^{1,2}$ & 29.1 & 29.0 & 29.0 \\
\hline \multicolumn{4}{|l|}{ Nutrient composition } \\
\hline $\mathrm{CP}, \%$ of $\mathrm{DM}$ & 11.2 & 12.8 & 11.2 \\
\hline $\mathrm{ADF}, \%$ of $\mathrm{DM}$ & 28.3 & 26.9 & 28.1 \\
\hline $\mathrm{NDF}, \%$ of DM & 45.5 & 42.0 & 45.0 \\
\hline Ash, $\%$ of DM & 7.1 & 7.7 & 6.4 \\
\hline $\mathrm{Ca}, \%$ of $\mathrm{DM}$ & 0.73 & 0.76 & 0.70 \\
\hline $\mathrm{P}, \%$ of $\mathrm{DM}$ & 0.34 & 0.35 & 0.33 \\
\hline $\mathrm{Mg}, \%$ of $\mathrm{DM}$ & 0.32 & 0.34 & 0.33 \\
\hline $\mathrm{Na}, \%$ of $\mathrm{DM}$ & 0.06 & 0.05 & 0.06 \\
\hline $\mathrm{K}, \%$ of $\mathrm{DM}$ & 1.34 & 1.33 & 1.09 \\
\hline $\mathrm{S}, \%$ of $\mathrm{DM}$ & 0.16 & 0.19 & 0.17 \\
\hline $\mathrm{Cl}, \%$ of $\mathrm{DM}$ & 0.92 & 0.63 & 0.19 \\
\hline $\mathrm{Fe}, \mathrm{mg} / \mathrm{kg}$ & 529 & 516 & 516 \\
\hline $\mathrm{Mn}, \mathrm{mg} / \mathrm{kg}$ & 195 & 224 & 189 \\
\hline $\mathrm{Zn}, \mathrm{mg} / \mathrm{kg}$ & 368 & 360 & 364 \\
\hline $\mathrm{Cu}, \mathrm{mg} / \mathrm{kg}$ & 45.7 & 46.5 & 44.2 \\
\hline $\mathrm{DCAD}^{3}, \mathrm{mEq}$ per $100 \mathrm{~g}$ of $\mathrm{DM}$ & 0.7 & 7.3 & 14.4 \\
\hline
\end{tabular}

${ }^{1}$ Contained $24.0 \%$ ground corn grain, $20.0 \%$ rolled corn grain, $20.0 \%$ soybean meal, $15.0 \%$ dehydrated beet pulp, $4.0 \%$ corn gluten meal, $4.0 \%$ SoyPlus (West Central Coop., Ralston, IA), $3.0 \%$ rolled barley, $2.8 \%$ mineral and vitamin mix, $2.5 \%$ molasses, $2.0 \%$ canola meal, $1.8 \%$ limestone, and $1.0 \%$ canola oil on an as-fed basis. ${ }^{2}$ Nutrient composition on a DM basis, $22.2 \%$ CP, $7.3 \%$ ADF, $13.5 \%$ NDF, $11.0 \%$ ash, $1.88 \%$ Ca, $0.91 \%$ P, $0.19 \% \mathrm{Na}, 0.92 \% \mathrm{~K}, 0.87 \% \mathrm{Mg}, 0.35 \% \mathrm{~S}, 0.56 \% \mathrm{Cl}, 1,746 \mathrm{mg} / \mathrm{kg} \mathrm{Fe}, 636 \mathrm{mg} / \mathrm{kg}$ of $\mathrm{Mn}, 1,277 \mathrm{mg} / \mathrm{kg}$ of Zn, 145 $\mathrm{mg} / \mathrm{kg}$ of $\mathrm{Cu}, 25,000 \mathrm{IU} / \mathrm{kg}$ of vitamin A, 6,000 IU $/ \mathrm{kg}$ of vitamin $\mathrm{D}, 360 \mathrm{IU} / \mathrm{kg}$ of vitamin $\mathrm{E}$, and $-7.3 \mathrm{mEq}$ per $100 \mathrm{~g}$ of DCAD.

${ }^{3}$ Calculated as $\mathrm{Na}^{+}+\mathrm{K}^{+}-\mathrm{Cl}^{-}-\mathrm{S}^{2-}$ (Ender et al., 1971). 
30 min during the recovery time. Blood samples were transferred to tubes containing lithium heparin (Fisher Scientific Co., Nepean, ON, Canada) and immediately analyzed for $\mathrm{pH}$, partial pressure of $\mathrm{CO}_{2}\left(\mathbf{p C O}_{2}\right)$ and concentrations of blood iCa, bicarbonate, sodium ion, and potassium ion using an auto analyzer (GEM Premier 3000, Instrumentation Laboratory, Richmond Hill, ON, Canada). Additional blood samples were collected every $2 \mathrm{~h}$ during the infusion and recovery time, transferred into tubes containing sodium heparin (Fisher Scientific Co.), and centrifuged at 3,000 $\times g$ for $20 \mathrm{~min}$ at $4^{\circ} \mathrm{C}$. Following centrifugation, the plasma was harvested and stored at $-20^{\circ} \mathrm{C}$. The plasma samples were analyzed for concentrations of PTH and 1,25- $(\mathrm{OH})_{2}$ D by the Diagnostic Centre for Population Animal Health (Lansing, MI) using a 2-site immunoradiometric assay (Diagnostic Systems Laboratory, Webster, TX) and a DiaSorin 1,25- $(\mathrm{OH})_{2}$ D RIA kit (DiaSorin, Stillwater, $\mathrm{MN}$ ), respectively, as described previously (Penner et al., 2008).

Feed samples were collected on d 13 and 14 of each period, and oven-dried at $55^{\circ} \mathrm{C}$ for $48 \mathrm{~h}$ for determination of DM concentration. Dried samples were ground through a 1-mm screen with a Wiley mill (ThomasWiley, Philadelphia, PA), and sent to Cumberland Valley Analytical Service (Hagerstown, MD) to determine concentrations of NDF (Van Soest et al., 1991), ADF (AOAC, 2000; method 973.18), CP (AOAC, 2000; method 990.03), ash (AOAC, 2000; method 942.05), and minerals (AOAC, 2000; method 985.01). The concentrations of $\mathrm{S}$ and $\mathrm{Cl}$ were determined using Leco S144DR Sulfur Combustion Analyzer (Leco, St. Joseph, MI) and Corning 925 Chloride Analyzer (Ciba Corning Diagnostics, Medfield, MA), respectively. The DCAD (mEq per $100 \mathrm{~g}$ of $\mathrm{DM}$ ) was calculated as $\mathrm{Na}^{+}+\mathrm{K}^{+}-$ $\mathrm{Cl}^{-}-\mathrm{S}^{2-}$ (Ender et al., 1971).

\section{Statistical Analysis}

All data were analyzed using the fit model procedure of the JMP software (version 5.1, SAS Inc., Cary, NC) according to the following model:

$$
\mathrm{Y}_{\mathrm{ijk} \mathrm{k}}=\mu+\mathrm{C}_{\mathrm{i}}+\mathrm{P}_{\mathrm{j}}+\mathrm{T}_{\mathrm{k}}+\mathrm{e}_{\mathrm{ijk} \mathrm{l}},
$$

where $\mu=$ overall mean, $\mathrm{C}_{\mathrm{i}}=$ random effect of cow (i $=1$ to 6$), \mathrm{P}_{\mathrm{j}}=$ fixed effect of period $(\mathrm{j}=1$ to 3$), \mathrm{T}_{\mathrm{k}}$ $=$ fixed effect of treatment $(\mathrm{k}=1$ to 3$)$, and $\mathrm{e}_{\mathrm{ijk}}=$ residual, assumed to be normally distributed.

Urine $\mathrm{pH}$ was measured on $\mathrm{d} 6$ and 12 for each period, and day $\times$ treatment interaction was originally included in the model. However, because the interaction was not significant, it was removed from the statistical model, and means averaged for each period were evaluated using the statistical model described above. For the statistical analyses of the resistance time and recovery time, the initial blood iCa concentration was added to the model above as a covariate. One cow was extremely resistant to the EDTA challenge, and its blood iCa did not decrease to $60 \%$ of the initial concentration. Data from this cow were excluded for statistical analysis as an outlier. Treatment effect was declared at $P \leq 0.05$, and Student's $t$-test was conducted to separate treatment means.

\section{RESULTS AND DISCUSSION}

\section{Acid-Base Balance}

When cows were fed the LOW diet, urine $\mathrm{pH}$ decreased compared with when fed the HIGH diet (6.88 vs. 7.83; Table 3), but there was no significant difference between the MED diet $(7.15 \pm 0.21)$ and the LOW or HIGH diet in urinary $\mathrm{pH}$. However, blood $\mathrm{pH}$ was significantly lower for the LOW and MED diets compared with the $\mathrm{HIGH}$ diet (7.44 vs. 7.47). The $\mathrm{pCO}_{2}$ and concentrations of $\mathrm{iCa}, \mathrm{Na}^{+}$, and $\mathrm{K}^{+}$did not differ significantly for the blood samples collected immediately before the EDTA challenge, although there was a tendency for the treatment effect on the $\mathrm{HCO}_{3}{ }^{-}$concentration $(P=0.09)$. These observations were consistent with previous findings that reducing the DCAD decreases blood $\mathrm{pH}$, urine $\mathrm{pH}$, and $\mathrm{HCO}_{3}{ }^{-}$concentrations (Block, 1994). In general, blood $\mathrm{pH}$ shows much less variation compared with urine $\mathrm{pH}$ because of strong homeostatic mechanisms (Spanghero, 2004), and urine $\mathrm{pH}$ is another indicator for acid-base status (Goff et al., 2004). The target urinary $\mathrm{pH}$ that indicates effective anion administration is 5.5 to 6.2 (Horst et al., 1997), and the urine $\mathrm{pH}$ observed in the present study was higher than this threshold. However, the blood $\mathrm{pH}$ data from the present study indicate that a DCAD of 7.3 $\mathrm{mEq}$ per $100 \mathrm{~g}$ DM or less (i.e., MED or LOW) is sufficient to decrease blood pH. Charbonneau et al. (2006) suggested that mean urinary $\mathrm{pH}$ does not need to be reduced below 7.0 to prevent clinical milk fever.

The treatment effects on acid-base balance continued to be observed during the EDTA challenge. During the infusion of EDTA solution, minimum blood $\mathrm{pH}$ was lower when cows were fed the MED or LOW diet compared with the HIGH diet (7.32 vs. 7.35; Table 4) although mean and maximum blood $\mathrm{pH}$ were similar among the treatments. Similarly, mean blood $\mathrm{HCO}_{3}{ }^{-}$concentration was less for the LOW and MED diets than for the HIGH diet (23.6 and 23.9 vs. $26.5 \mathrm{mM}$ ). Metabolic alkalosis caused by excess dietary cation intake may be an underlying cause of hypocalcemia, and a reduction in blood $\mathrm{pH}$ is expected to improve $\mathrm{Ca}$ absorption from 
Table 3. Urine $\mathrm{pH}$, jugular vein blood $\mathrm{pH}$ and $\mathrm{pCO}_{2}$, and blood concentrations of ionized $\mathrm{Ca}(\mathrm{iCa}), \mathrm{Na}^{+}, \mathrm{K}^{+}$, and $\mathrm{HCO}_{3}{ }^{-}$before the induction of hypocalcemia by intravenous infusion of EDTA for cows fed the low- $(0.7$ $\mathrm{mEq} / 100 \mathrm{~g}$ of DM), medium- $(7.3 \mathrm{mEq} / 100 \mathrm{~g}$ of DM), and high- $(14.4 \mathrm{mEq} / 100 \mathrm{~g}$ of DM) DCAD diets

\begin{tabular}{|c|c|c|c|c|c|}
\hline \multirow[b]{2}{*}{ Variable } & \multicolumn{3}{|c|}{ Dietary treatment } & \multirow[b]{2}{*}{$\mathrm{SE}$} & \multirow[b]{2}{*}{$P$-value } \\
\hline & Low DCAD & Medium DCAD & High DCAD & & \\
\hline Urine $\mathrm{pH}$ & $6.88^{\mathrm{b}}$ & $7.15^{\mathrm{a}, \mathrm{b}}$ & $7.83^{\mathrm{a}}$ & 0.21 & 0.04 \\
\hline \multicolumn{6}{|l|}{ Blood } \\
\hline $\mathrm{pH}$ & $7.44^{\mathrm{b}}$ & $7.44^{\mathrm{b}}$ & $7.47^{\mathrm{a}}$ & 0.01 & 0.01 \\
\hline $\mathrm{pCO}_{2}, \mathrm{~mm} \mathrm{Hg}$ & 39.9 & 39.0 & 40.2 & 1.3 & 0.71 \\
\hline $\mathrm{iCa}, \mathrm{m} M$ & 1.18 & 1.16 & 1.15 & 0.02 & 0.44 \\
\hline $\mathrm{Na}^{+}, \mathrm{m} M$ & 139 & 140 & 139 & 1 & 0.45 \\
\hline $\mathrm{K}^{+}, \mathrm{m} M$ & 3.83 & 3.61 & 3.57 & 0.14 & 0.14 \\
\hline $\mathrm{HCO}_{3}^{-}, \mathrm{m} M$ & 27.0 & 26.4 & 29.5 & 0.9 & 0.09 \\
\hline
\end{tabular}

${ }^{\mathrm{a}, \mathrm{b}}$ Treatment means with different superscripts within a row were significantly different $(P<0.05)$.

the intestine as well as bone Ca resorption by improving the sensitivity of peripheral tissues to PTH (Goff et al., 1991). Therefore, both LOW and MED diets would allow greater capability to maintain $\mathrm{Ca}$ homeostasis because small changes in blood $\mathrm{pH}$ have large impacts on the extent of Ca resorption (Arnett, 2007).

\section{Capability to Maintain Ca Homeostasis}

Hypocalcemia can be induced by intravenous infusion of EDTA solution. The EDTA forms a chelate with Ca ions (Jorgensen et al., 1999; Liesegang et al., 2000) and restricts Ca availability to the cow. Infusion of EDTA is an efficient means to induce hypocalcemia, and the EDTA challenge protocol is often used as a model to examine the effect of DCAD on the physiological responses (Schonewille et al., 1999). In the present study, the time required to reduce blood iCa concentration to $60 \%$ of the initial values was not significantly different among the 3 treatments $(P=0.14$; Table 5; Figure 1$)$. However, the time required to recover to $90 \%$ of the

Table 4. Jugular vein blood $\mathrm{pH}$ and partial pressure of $\mathrm{CO}_{2}\left(\mathrm{pCO}_{2}\right)$, blood concentrations of $\mathrm{Na}^{+}, \mathrm{K}^{+}$, and $\mathrm{HCO}_{3}{ }^{-}$, and plasma concentrations of parathyroid hormone $(\mathrm{PTH})$ and 1,25-dihydroxyvitamin D $\left[1,25-(\mathrm{OH})_{2}\right.$ $\mathrm{D}]$ during intravenous infusion of EDTA for cows fed the low- $(0.7 \mathrm{mEq} / 100 \mathrm{~g}$ of DM), medium- $(7.3 \mathrm{mEq} / 100$ $\mathrm{g}$ of $\mathrm{DM})$, and high- $(14.4 \mathrm{mEq} / 100 \mathrm{~g}$ of DM) DCAD diets.

\begin{tabular}{|c|c|c|c|c|c|}
\hline \multirow[b]{2}{*}{ Variable } & \multicolumn{3}{|c|}{ Dietary treatment } & \multirow[b]{2}{*}{$\mathrm{SE}$} & \multirow[b]{2}{*}{$P$-value } \\
\hline & Low DCAD & Medium DCAD & High DCAD & & \\
\hline \multicolumn{6}{|l|}{ Blood pH } \\
\hline Minimum & $7.32^{\mathrm{b}}$ & $7.32^{\mathrm{b}}$ & $7.35^{\mathrm{a}}$ & 0.01 & 0.01 \\
\hline Mean & 7.39 & 7.38 & 7.40 & 0.02 & 0.74 \\
\hline Maximum & 7.45 & 7.45 & 7.48 & 0.01 & 0.17 \\
\hline \multicolumn{6}{|c|}{$\mathrm{pCO}_{2}, \mathrm{~mm} \mathrm{Hg}$} \\
\hline Minimum & 35.5 & 36.2 & 37.1 & 0.8 & 0.40 \\
\hline Mean & 39.5 & 40.1 & 41.4 & 0.6 & 0.13 \\
\hline Maximum & 46.7 & 45.9 & 47.3 & 0.9 & 0.56 \\
\hline \multicolumn{6}{|l|}{$\mathrm{Na}^{+}, \mathrm{m} M$} \\
\hline Minimum & 139 & 138 & 136 & 1.2 & 0.22 \\
\hline Mean & 142 & 141 & 141 & 0.3 & 0.50 \\
\hline Maximum & 145 & 144 & 144 & 0.4 & 0.52 \\
\hline \multicolumn{6}{|l|}{$\mathrm{K}^{+}, \mathrm{m} M$} \\
\hline Minimum & $3.12^{\mathrm{a}}$ & $3.15^{\mathrm{a}}$ & $2.73^{\mathrm{b}}$ & 0.08 & 0.01 \\
\hline Mean & $3.53^{\mathrm{a}}$ & $3.49^{\mathrm{a}}$ & $3.14^{\mathrm{b}}$ & 0.05 & $<0.01$ \\
\hline Maximum & $4.16^{\mathrm{a}}$ & $4.04^{\mathrm{a}, \mathrm{b}}$ & $3.66^{\mathrm{b}}$ & 0.11 & 0.04 \\
\hline \multicolumn{6}{|l|}{$\mathrm{HCO}_{3}^{-}, \mathrm{m} M$} \\
\hline Minimum & $20.6^{\mathrm{b}}$ & $20.5^{\mathrm{b}}$ & $23.4^{\mathrm{a}}$ & 0.7 & 0.03 \\
\hline Mean & $23.6^{\mathrm{b}}$ & $23.9^{\mathrm{b}}$ & $26.5^{\mathrm{a}}$ & 0.6 & 0.03 \\
\hline Maximum & 28.5 & 29.0 & 30.7 & 0.9 & 0.24 \\
\hline \multicolumn{6}{|l|}{ PTH, pM } \\
\hline Minimum & 1.76 & 1.11 & 1.30 & 0.50 & 0.13 \\
\hline Mean & 2.90 & 2.09 & 2.24 & 0.70 & 0.12 \\
\hline Maximum & $5.12^{\mathrm{a}}$ & $3.27^{\mathrm{b}}$ & $3.33^{\mathrm{b}}$ & 0.97 & 0.05 \\
\hline \multicolumn{6}{|c|}{$1,25(\mathrm{OH})_{2} \mathrm{D}, \mathrm{p} M$} \\
\hline Minimum & 54.9 & 40.1 & 71.4 & 8.5 & 0.08 \\
\hline Mean & $102^{\mathrm{a}, \mathrm{b}}$ & $70.5^{\mathrm{b}}$ & $131^{\mathrm{a}}$ & 14.7 & 0.03 \\
\hline Maximum & $152^{\mathrm{a}, \mathrm{b}}$ & $99.6^{\mathrm{b}}$ & $200^{\mathrm{a}}$ & 19.5 & 0.02 \\
\hline
\end{tabular}

${ }^{\mathrm{a}, \mathrm{b}}$ Treatment means with different superscripts within a row were significantly different $(P \leq 0.05)$. 
initial blood iCa concentration was less for cows fed the LOW diet compared with those fed the MED and HIGH diets (185 vs. 248 and 263 min, respectively; Figure 2). Although both MED and LOW diets were effective at decreasing blood $\mathrm{pH}$, the capability to recover from the induced hypocalcemia was improved only for cows fed the LOW diet. Similarly, Charbonneau et al. (2008) fed a low-DCAD timothy diet and control (DCAD = -2.4 vs. $29.6 \mathrm{mEq}$ per $100 \mathrm{~g}$ of DM, respectively), and reported that cows fed the low-DCAD diet recovered from the induced hypocalcemia sooner than cows fed the control diet (from 50 to $95 \%$ of initial blood iCa concentration; 339 vs. $708 \mathrm{~min} ; P<0.01$ ).

The EDTA challenge protocol provides valuable information by simulating hypocalcemia that postpartum cows often experience, although some differences exist between actual clinical hypocalcemia and hypocalcemia induced by the EDTA infusion. For example, postpartum cows have variable nadirs in blood iCa concentration whereas the iCa nadirs were similar for all treatments in the present study because we stopped EDTA infusion when blood iCa decreased to $60 \%$ of the initial concentrations. Furthermore, cows used in the present study had a relatively short recovery time from the in- duced hypocalcemia regardless of treatment (i.e., 185 to $263 \mathrm{~min}$ ), whereas postpartum lactating cows take more than $1 \mathrm{~d}$ to recover from actual hypocalcemia (Moore et al., 2000), which is likely attributed to far greater Ca demands for lactation. However, the recovery time from the EDTA challenge in nonpregnant nonlactating cows is expected to be a good indicator of the capability to maintain $\mathrm{Ca}$ homeostasis in lactating dairy cows immediately after calving. Penner et al. (2008) fed prepartum dry cows with low- or high-DCAD timothy from the same lots used in the current study, and found that the blood iCa nadir during the periparturient period was greater for cows fed low-DCAD timothy hay.

The concentrations of PTH and $1,25(\mathrm{OH})_{2} \mathrm{D}$ in the plasma are highly regulated by blood iCa. Ramberg et al. (1967) showed that, in multiparous cows, blood PTH concentration increased within 15 min after the initiation of EDTA infusion. In the present study, the mean plasma PTH concentration during the EDTA challenge did not differ across the treatments (Table 4), but the maximum PTH concentration during the infusion was slightly greater for the LOW treatment compared with the MED and HIGH treatments (5.12 vs. 3.27 and 3.33 $\mathrm{p} M)$. The mean plasma $1,25(\mathrm{OH})_{2} \mathrm{D}$ concentration was

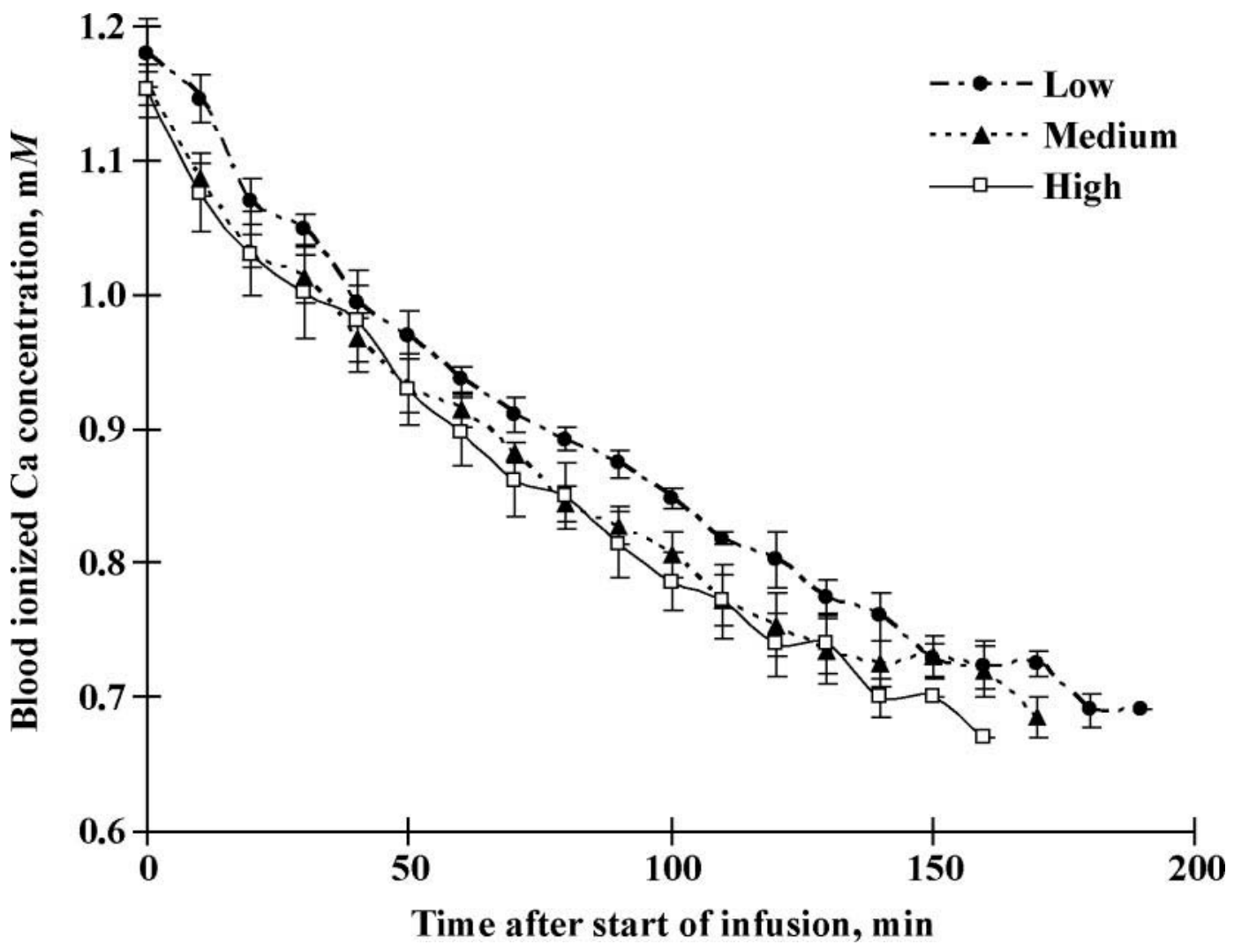

Figure 1. Changes in blood ionized Ca concentration during the infusion of EDTA solution when cows were fed the low- $(0.7 \mathrm{mEq}$ per 100 $\mathrm{g}$ of DM), medium- $(7.3 \mathrm{mEq}$ per $100 \mathrm{~g}$ of DM), and high- $(14.4 \mathrm{mEq}$ per $100 \mathrm{~g}$ of DM) DCAD diets. 


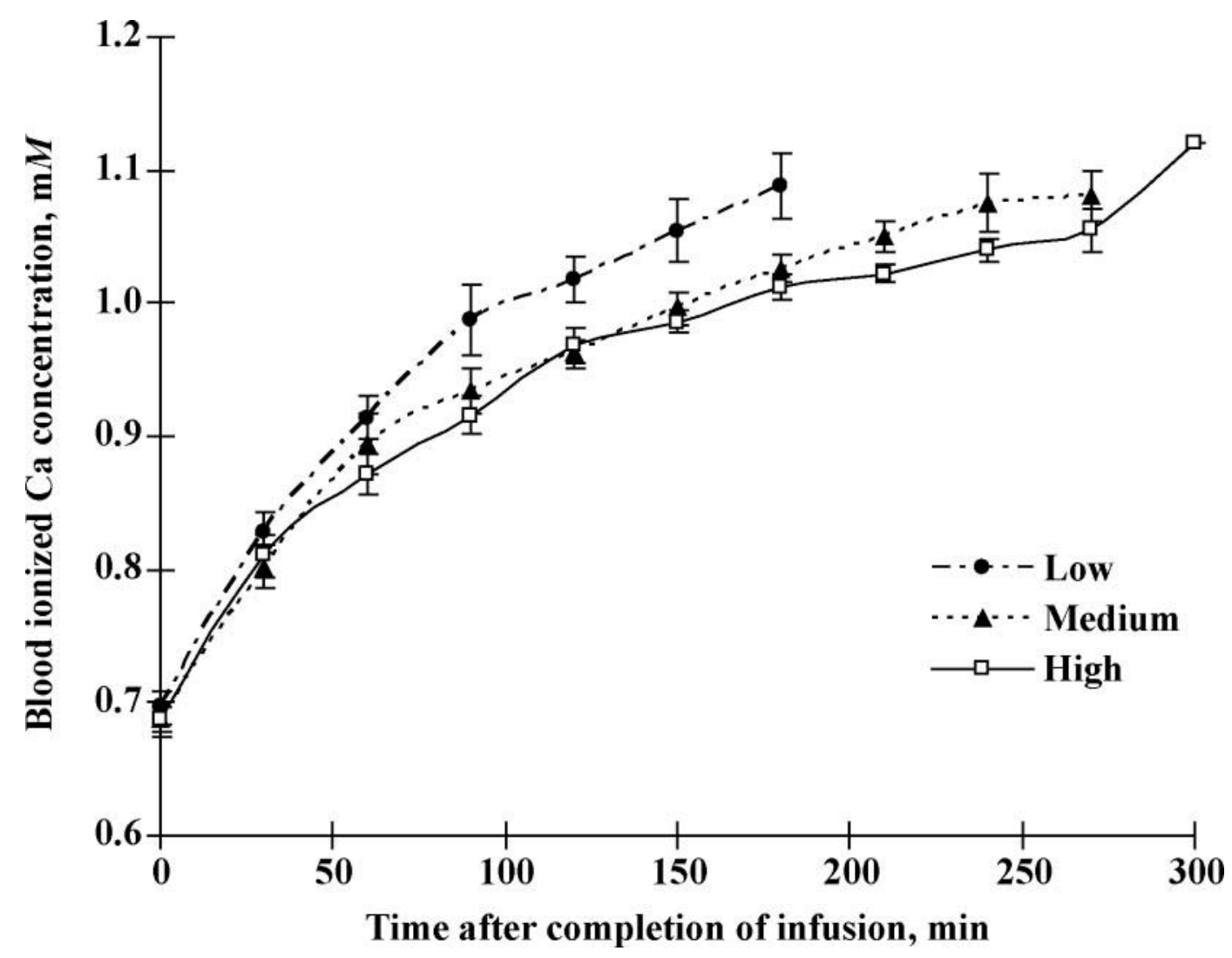

Figure 2. Changes in blood ionized Ca concentration during the recovery from the induced hypocalcaemia when cows were fed the low- (0.7 $\mathrm{mEq}$ per $100 \mathrm{~g}$ of $\mathrm{DM})$, medium- $(7.3 \mathrm{mEq}$ per $100 \mathrm{~g}$ of $\mathrm{DM})$, and high- $(14.4 \mathrm{mEq}$ per $100 \mathrm{~g}$ of DM) DCAD diets.

slightly less for the MED than the HIGH treatment (70.5 vs. $131 \mathrm{pM}$ ), but neither differed from the LOW treatment (Table 4). Although we noted some treatment effects on the plasma concentrations of PTH and $1,25(\mathrm{OH})_{2} \mathrm{D}$, these might not be biologically important; the range of variations during the EDTA challenge was far smaller than the typical range of variations found in periparturient cows, 10 to $60 \mathrm{p} M$ for PTH (Goff and Horst, 1997) and 250 to $750 \mathrm{p} M$ for $1,25(\mathrm{OH})_{2} \mathrm{D}$ concentrations (Horst et al., 1994). Contrary to our study, Penner et al. (2008) observed that plasma concentrations of PTH and $1,25(\mathrm{OH})_{2}$ D peaked at 5.58 and 338 $\mathrm{p} M$, respectively, at $24 \mathrm{~h}$ after parturition when they fed the same lot of LOW timothy hay to prepartum dry cows. The lack of biologically noteworthy increases in PTH and $1,25(\mathrm{OH})_{2}$ D concentrations for the present study might be attributed to the short duration (i.e., $<3 \mathrm{~h}$ ) of EDTA challenge.

Recovery of Ca from the urine may not be sufficient to replace the Ca loss to EDTA chelation. If all EDTA that was infused into the cows chelated iCa in the blood, 236 $\pm 8.7 \mathrm{mM}$ of Ca would be trapped by EDTA infusion in the present study. In another EDTA challenge study, Schonewille et al. (1999) reported that $303 \mathrm{mmol}$ of iCa was trapped by EDTA and only $27 \mathrm{mmol}$ was recovered from the urine, whereas bone resorption accounted for

Table 5. Time ( $\mathrm{min}$ ) required for the intravenous infusion of EDTA solution to decrease blood ionized Ca concentration to $60 \%$ (resistance time) and to recover to $90 \%$ (recovery time) of the initial concentration determined immediately before the start of the infusion when cows were fed the low- $(0.7 \mathrm{mEq}$ per $100 \mathrm{~g}$ of DM), medium- $(7.3 \mathrm{mEq}$ per $100 \mathrm{~g}$ of DM), and high- $(14.4 \mathrm{mEq}$ per $100 \mathrm{~g}$ of DM) DCAD diets

\begin{tabular}{lcccc}
\hline & \multicolumn{3}{c}{ Dietary treatment } & \\
\cline { 2 - 4 } Variable & Low DCAD & Medium DCAD & High DCAD & SE \\
\hline Resistance time, min & 169 & 158 & 137 & 10 \\
Recovery time, min & $185^{\mathrm{b}}$ & $248^{\mathrm{a}}$ & $263^{\mathrm{a}}$ & 0.14 \\
\hline
\end{tabular}

\footnotetext{
${ }^{\mathrm{a}, \mathrm{b}}$ Treatment means with different superscripts within a row were significantly different $(P<0.01)$.
} 
more than $50 \%$ of the Ca recovery. Thus, Ca recovery after the EDTA challenge likely requires Ca resorption from the bone in our study. Feeding low-DCAD diets makes cows more tolerant to the hypocalcemic stress by increasing the sensitivity of bone receptors to PTH (Horst et al. 1997) and increasing the activity of osteoclasts and Ca resorption (Spanghero 2004). Therefore, cows fed the LOW diet might be able to recover from the EDTA challenge sooner without increasing plasma concentrations of PTH and $1,25(\mathrm{OH})_{2}$ D. However, the recovery time from the induced hypocalcemia was not decreased for cows fed the MED compared with those fed the HIGH diet although the MED diet successfully decreased blood $\mathrm{pH}$.

Diets with a low but positive DCAD can improve the capability of dairy cows to maintain Ca homeostasis to some extent (Kurosaki et al., 2007; Penner et al. 2008), but may not completely eliminate the prevalence of hypocalcemia. Moore et al. (2000) reported that 50\% of cows fed a diet with $0 \mathrm{mEq}$ per $100 \mathrm{~g}$ of $\mathrm{DM}$ were diagnosed with subclinical hypocalcemia (plasma iCa $<1.0 \mathrm{mM}$ ), and Kurosaki et al. (2007) reported 11\% severe hypocalcemia (total serum $\mathrm{Ca}<1.25 \mathrm{mM}$ ) for cows fed $1.2 \mathrm{mEq}$ per $100 \mathrm{~g}$ of DM. Similarly, Penner et al. (2008) reported $35 \%$ of cows fed a diet with $1.6 \mathrm{mEq}$ per $100 \mathrm{~g}$ of DM were still diagnosed with subclinical hypocalcemia (blood iCa $<1 \mathrm{mM}$ ). In the present study, the LOW diet $(0.7 \mathrm{mEq}$ per $100 \mathrm{~g}$ of $\mathrm{DM})$ was effective at improving $\mathrm{Ca}$ homeostasis, but not the MED (7.3 mEq per $100 \mathrm{~g}$ of DM) or HIGH (14.4 mEq per 100 $\mathrm{g}$ of $\mathrm{DM})$ diets.

\section{Blood Potassium Concentration}

Mean blood $\mathrm{K}^{+}$concentration was greater for the LOW and MED treatments compared with the HIGH treatment (3.53 and 3.49 vs. $3.14 \mathrm{mM}$, respectively; Table 4). The blood $\mathrm{Na}^{+}$concentration was not affected by treatment in the present study, which agrees with Fenwick and Daniel (1992). Regardless of the dietary treatment, blood $\mathrm{K}^{+}$concentration decreased during intravenous infusion of EDTA solution. A similar reduction in blood $\mathrm{K}^{+}$concentration is observed for spontaneous milk fever with severe clinical signs (Littledike et al., 1969). Low $\mathrm{K}^{+}$concentration during the EDTA challenge may be a physiological consequence of hypocalcemia; the stress associated with hypocalcemia may cause elevation of plasma ACTH, which could contribute to the reduction of blood $\mathrm{K}^{+}$concentration during hypocalcemia (Daniel, 1980). Our results indicate that cows fed the HIGH diet had a significantly lesser mean blood $\mathrm{K}^{+}$concentration than those fed LOW and MED diets. Thus, cows with a greater ability to mobilize Ca during the induced hypocalcemia may experience less physiological stress. Schonewille et al. (1999) reported that cows fed a high anion diet tended to decrease $\mathrm{K}$ excretion in urine compared with those fed a high cation diet. Cows fed LOW and MED diets, in the present study, might be able to maintain greater blood $\mathrm{K}^{+}$concentration during the induced hypocalcemia compared with those fed HIGH diet by decreasing the urinary $\mathrm{K}$ excretion.

\section{CONCLUSIONS}

Feeding the LOW- or MED-DCAD timothy diet decreased blood $\mathrm{pH}$ compared with the HIGH-DCAD timothy diet. However, only the LOW diet allowed for faster recovery from the induced hypocalcemia. A diet with DCAD values of $7.3 \mathrm{mEq}$ per $100 \mathrm{~g}$ of DM or less may be effective at decreasing blood $\mathrm{pH}$. However, the capability of dairy cows to maintain Ca homeostasis may not be enhanced unless the DCAD is reduced to 1 $\mathrm{mEq}$ per $100 \mathrm{~g}$ of DM.

\section{ACKNOWLEDGMENTS}

The authors thank the staff of the Metabolic Unit for general animal husbandry, and L. M. Kutryk, G. B. Penner, and T. D. Whyte at the University of Alberta (Edmonton, Alberta, Canada) for technical assistance. Financial support from Zen-Raku-Ren (Japanese Federation of Dairy Cooperative Associations), Advancing Canadian Agriculture, and Agri-Food program of Agriculture and Food Council, and Alberta Milk are gratefully acknowledged.

\section{REFERENCES}

AOAC. 2000. Official Methods of Analysis. 17th ed. Association of Official Analytical Chemists, Arlington, VA.

Arnett, T. 2007. Acid-base regulation of bone metabolism. Int. Congr. Ser. 1297:255-267.

Block, E. 1994. Manipulation of dietary cation-anion difference on nutritionally related production diseases, productivity, and metabolic responses of dairy cows. J. Dairy Sci. 77:1437-1450.

Charbonneau, E., P. Y. Chouinard, G. F. Tremblay, G. Allard, and D. Pellerin. 2008. Hay to reduce dietary cation-anion difference of dairy cows. J. Dairy Sci. 91:1585-1596.

Charbonneau, E., D. Pellerin, and G. R. Oetzel. 2006. Impact of lowering dietary cation-anion difference in nonlactating dairy cows: A meta-analysis. J. Dairy Sci. 89:537-548.

Daniel, R. C. W. 1980. Induced hypocalcaemia in cows and sheep II: Changes in plasma potassium levels. Br. Vet. J. 136:45-50.

Ender, F., I. W. Dishington, and A. Helgebostad. 1971. Calcium balance studies in dairy cows under experimental induction and prevention of hypocalcaemic paresis puerperalis. Z. Tierphysiol. Tierer. 28:233-256.

Fenwick, D. C., and C. W. Daniel. 1992. The effects of hypocalcaemia due to a 4-hour infusion of $\mathrm{Na}_{2}$ EDTA solution on various blood and urine analytes in dairy cows and a comparison of these effects between cows with high and low erythrocyte potassium concentrations. Br. Vet. J. 148:283-296.

Goff, J. P., and R. L. Horst. 1997. Effects of the addition of potassium or sodium, but not calcium, to prepartum rations on milk fever in dairy cows. J. Dairy Sci. 80:176-186. 
Goff, J. P., R. L. Horst, F. J. Mueller, J. K. Miller, G. A. Kiess, and H. H. Dowlen. 1991. Addition of chloride to a prepartal diet high in cations increases 1,25-dihydroxyvitamin D response to hypocalcaemia preventing milk fever. J. Dairy Sci. 74:38633871.

Goff, J. P., R. Ruiz, and R. L. Horst. 2004. Relative acidifying activity of anionic salts commonly used to prevent milk fever. J. Dairy Sci. $87: 1245-1255$.

Horst, R. L., J. P. Goff, and T. A. Reinhardt. 1994. Calcium and vitamin D metabolism in the dairy cows. J. Dairy Sci. 77:19361951.

Horst, R. L., J. P. Goff, T. A. Reinhardt, and D. R. Buxton. 1997. Strategies for preventing milk fever in dairy cattle. J. Dairy Sci. 80:1269-1280

Jorgensen, R. J., N. R. Nyengaard, R. C. W. Daniel, L. S. B. Mellau, and J. M. D. Enemark. 1999. Induced hypocalcaemia by $\mathrm{Na}_{2}$ EDTA infusion: A review. J. Vet. Med. A 46:389-407.

Kurosaki, N., O. Yamato, J. Sata, F. Mori, S. Imoto, and Y. Maede. 2007. Preventive effect of mildly altering dietary cation-anion difference on milk fever in dairy cows. J. Vet. Med. Sci. 69:185192 .

Liesegang, A., R. Eicher, M. L. Sassi, J. Ristelli, J. L. Riond, and M. Wanner. 2000. The course of selected bone resorption marker concentrations in response to short-term hypocalcaemia experimentally induced with disodium EDTA infusions in dairy cows. J. Vet. Med. A 47:477-487.

Littledike, E.T., S. C. Whipp, and M. S. Schroeder. 1969. Studies on parturient paresis. J. Am. Vet. Med. Assoc. 155:1955-1962.

Moore, S. J., M. J. VandeHaar, B. K. Sharma, T. E. Pilbeam, D. K. Beede, H. F. Bucholtz, J. S. Liesman, R. L. Horst, and J. P. Goff. 2000. Effects of altering dietary cation-anion difference on calcium and energy metabolism in peripartum cows. J. Dairy Sci. 83:2095-2104.

Oba, M., R. Holm, R. McKenzie, and T. Dow. 2007. Fertilization using potassium chloride decreased the DCAD of timothy hay. J. Dairy Sci. 90(Suppl. 1):512. (Abstr.)

Pelletier, S., G. Bélanger, G. F. Tremblay, P. Sequin, R. Drapeau, and G. Allard. 2007. Dietary cation-anion difference of timothy
(Phleum pratense L.) as influenced by application of chloride and nitrogen fertilizer. Grass Forage Sci. 62:66-77.

Pelletier, S., G. F. Tremblay, G. Bélanger, M. H. Chantigny, P. Sequin, R. Drapeau, and G. Allard. 2008. Nutritive value of timothy fertilized with $\mathrm{Cl}$ or $\mathrm{Cl}$-containing liquid swine manure. J. Dairy Sci. 91:713-721.

Penner, G. B., G. F. Tremblay, T. Dow, and M. Oba. 2008. Timothy hay with a low dietary cation-anion difference improves calcium homeostasis in periparturient Holstein cows. J. Dairy Sci 91:1959-1968.

Ramberg, C. F. Jr., G. P. Mayer, D. S. Kronfeld, G. D. Aurbach L. M. Sherwood, and J. T. Potts Jr. 1967. Plasma calcium and parathyroid hormone responses to EDTA infusion in the cow. Am. J. Physiol. 213:878-882.

Schonewille, J. T., A. T. Van't Klooster, H. Wouterse, and A. C. Beynen. 1999. Hypocalcaemia induced by intravenous administration of disodium ethylenediaminotetraacetate and its effects on excretion of calcium in urine of cows fed a high chloride diet. J. Dairy Sci. $82: 1317-1324$

Spanghero, M. 2004. Prediction of urinary and blood pH in nonlactating dairy cows fed anionic diets. Anim. Feed Sci. Technol. 116:83-92.

Tremblay, G. F., H. Brassard, G. Belanger, P. Seguin, R. Drapeau, A Bregard, R. Michaud, and G. Allard. 2006. Dietary cation anion difference of five cool season grasses. Agron. J. 98:339-348.

Van Soest, P. J., J. B. Robertson, and B. A. Lewis. 1991. Methods for dietary fiber, neutral detergent fiber, and nonstarch polysaccharides in relation to animal nutrition. J. Dairy Sci. 74:3583-3597.

Wang, C., and D. K. Beede. 1992. Effects of ammonia chloride and sulfate on acid base status and calcium metabolism of dry Jersey cows. J. Dairy Sci. 75:820-828.

Yarrington, J. T., C. C. Capen, H. E. Black, and R. Re. 1977. Effects of a low calcium prepartal diet on calcium homeostatic mechanisms in the cow morphologic and biochemical studies. J. Nutr. 107:2244-2256. 